\title{
Late-Holocene gallery forest retrogression in the Venezuelan Guayana: New data and implications for the conservation of a cultural landscape
}

\author{
Alejandra Leal,' Bibiana Bilbao,' Juan Carlos Berrio, ${ }^{2}$ \\ Hermann Behling, ${ }^{3}$ José Vicente Montoya ${ }^{4}$ and Carlos Méndez ${ }^{4}$
}

\begin{abstract}
Fire is considered a major threat to forest conservation in the Neotropics. Palaeoecological studies are critical for understanding the long-term interactions of climate, fire, and human activities in the savanna-forest dynamic. Here, new data from palynological analyses conducted in sedimentary records from the northern edge of the Amazon Basin, the Gran Sabana, southeast of Canaima National Park (CNP) are presented. Four radiocarbon ages from Quebrada Kowana (QK) and two for Ariwe Fernland (AF) records showed that both are late-Holocene age (with extrapolated basal ages of 3100 and 3400 cal. yr BP, respectively). Both showed the occurrence of gallery forest until 1800 (QK) and I600 (AF) cal. yr BP, with forest taxa reaching $60 \%$ and $40 \%$ of the terrestrial pollen sum, respectively. The main forest taxa were Celastraceae, Moraceae/Urticaceae, Schefflera, Protium, and Mahurea (QK) and Dimorphandra, Protium, Scheffera, Tachigali, and Blepharandra (AF). Savanna herbs (mainly Poaceae) reached 40-50\% (QK) and 60\% (AF). The high abundance of savanna herbs together with the low occurrence of mature forest taxa, and high abundance of pioneer taxa, suggests that the former forests comprised very open and disturbed forest-belts, surrounded by savannas. Since 1800 (QK) and I600 (AF) cal. yr BP, forest taxa dropped to 10\% and $5 \%$, respectively, suggesting the substitution of forests by herbaceous communities. The high abundance of charcoal recorded from the beginning of the records to about 1800-1600 cal. yr BP suggests that recurrent fires spreading from neighboring savannas were reaching the former forest, causing compositional changes and triggering forest reduction. Fires were very likely human-made, but highly controlled by climate. Hence, forest substitution happened when a combination of local fires and droughts was given in every record. Results agree with those from other localities in the CNP in confirming the occurrence of regional-scale gallery forest degradation during the late Holocene.
\end{abstract}

\section{Keywords}

Canaima National Park, fire management, gallery forest degradation, Gran Sabana, Guayana Shield, Holocene fires

Received 2I September 2015; revised manuscript accepted 10 December 2015

\section{Introduction}

In the upland savannas of Guayana, Canaima National Park (CNP), fire is considered a major threat to forests and biodiversity integrity. Conservation of this region is of importance given the many environmental services provided by these ecosystems and their high biological diversity. This was recognized when UNESCO listed the CNP as a World Heritage area in 1994. The presence of huge treeless savannas in the park, mainly in the southeastern portion (known as Gran Sabana) which is a predominantly humid region, has led to the popular belief that such grasslands are of recent anthropogenic origin (Sletto, 2008). As such, the region is considered a pilot area to test ecological models in the Neotropics, particularly in the context of global environmental change (Rull et al., 2012, 2015).

Results from actuo-ecological studies carried out during the last decades in the Gran Sabana suggest that the current forest/ savanna mosaics are the product of complex interactions between episodic droughts, catastrophic fire events, and a low potential recovery of native vegetation after disturbance (Dezzeo, 1994; Dezzeo and Chacón, 2005; Fölster, 1994). Since the CNP is also part of the Pemón indigenous lands and currently cultural burning is widespread in the park (Electrificación del Caroní (EDELCA), 2008), the modern vegetation assemblage has linked cultural burning with forest degradation, and has led to the implementation of expensive and inefficient fire exclusion and firefighting programs (Sletto, 2008). The main governmental stakeholders in the CNP are the National Electric Power Company (CORPOELEC) since the park was created to protect the headwaters of

\footnotetext{
'Departamento de Estudios Ambientales, Universidad Simón Bolívar, Venezuela

2Department of Geography, University of Leicester, UK

${ }^{3}$ Department of Palynology and Climate Dynamics, Georg-August-

Universität Göttingen, Germany

${ }^{4}$ Centro de Ecología, Instituto Venezolano de Investigaciones Científicas, Venezuela
}

Corresponding author:

Alejandra Leal, Departamento de Estudios Ambientales, Universidad Simón Bolívar, Valle de Sartenejas, Estado Miranda 1080, Venezuela. Email: avleal@usb.ve 

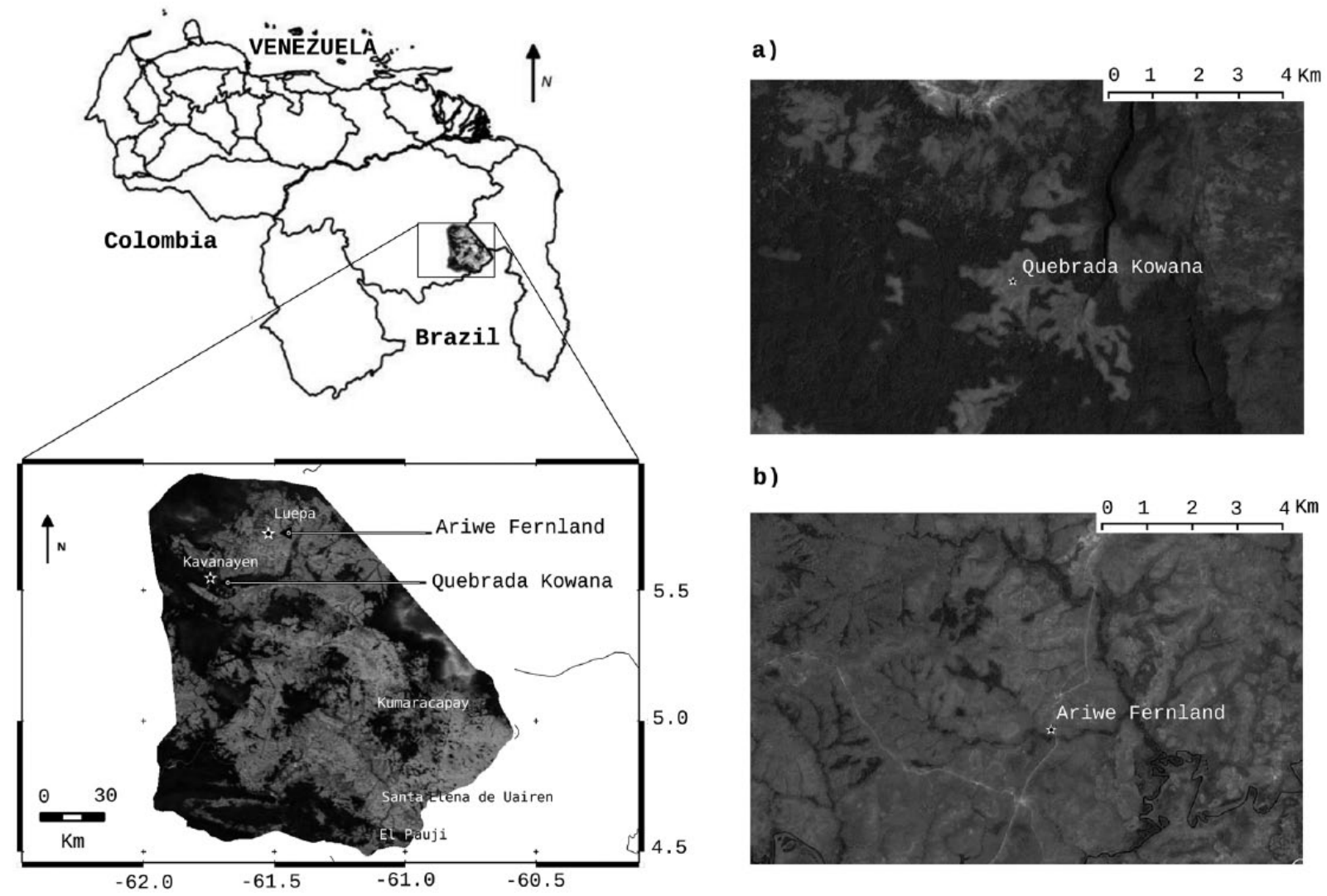

b)

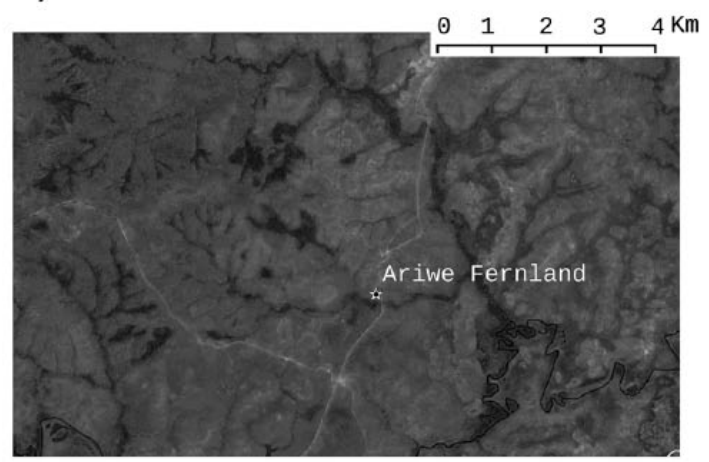

Figure I. Location of the Gran Sabana and studied localities, showing the main vegetation cover (dark gray: forests, light gray: savannas): (a) Quebrada Kowana and (b) Ariwe Fernland.A zoom of every studied site is shown in the panels at the right

Caroní River, which feeds the Guri dam and hydro-power station, which provides $75 \%$ of the electricity consumed in Venezuela. The National Institute of Parks (INPARQUES) is in turn the organization responsible for the CNP's conservation policies. Governmental stakeholder's perception on cultural burning seems to be influenced by the belief that indigenous fires cause the savannisation and even the desertification of the Gran Sabana (Rodríguez, 2004; Sletto, 2008). In contrast, Pemón indigenous inhabitants defend their right to practice their traditions in their ancestral lands and claim they are protecting and looking after the forests. This has led to a very complex conflict between the CNP inhabitants and governmental stakeholders (Rodríguez, 2007; Rodríguez et al., 2013), which obscures wider conservation goals.

Palaeoecological studies have provided important insights into the long-term interactions of climate and fire in the Gran Sabana (Rull et al., 2015). Available palynological records show the presence of extensive treeless savannas since the Pleistocene/ Holocene boundary, around 10,000 yr BP (Montoya et al., 2011a, 2011c; Rull, 2007, 2009; Rull et al., 2015), contradicting the perception that the current grasslands are a product of recent indigenous peoples' activities. Additionally, these studies demonstrate the occurrence of wildfires in the late Pleistocene (Montoya and Rull, 2011) and throughout the Holocene (Rull et al., 2015), showing that fire is not a recent occurrence. In these studies, it is also suggested that late glacial and early Holocene fires were of human origin, a hypothesis that needs to be tested against archaeological evidence (Rull et al., 2015). Palaeoecological studies also have shown that savanna fires were essential in the maintenance of extensive grasslands and preventing forest expansion, even during the wettest periods of the Holocene (Leal, 2010; Montoya and Rull, 2011). In addition, climate-fire feedbacks seem to have mediated the substitution of forest by savannas in some localities, with the vegetation replacement occurring in different moments during the Holocene, but mainly during the last two millennia (Montoya and Rull, 2011).
The studies summarized above and especially those referred to gallery forest dynamics were carried out in the southernmost portion of the Gran Sabana. Since an altitudinal gradient exists in the region (followed by rainfall and temperature gradients), and in general terms the Gran Sabana is today a highly heterogeneous area, palynological studies in the north of the region are needed to explore whether these palaeolandscape-vegetationfire processes inferred in the south are representative of the entire region. Here, we present the results of palynological studies conducted in the northernmost portion of the Gran Sabana. The records were obtained in locations where gallery forest is currently absent and herbaceous vegetation grows along riverbanks. The results are analyzed in the light of the long history of wildfires in the area, and the context of cultural burning practices and regional fire ecology, with the aim to provide relevant conclusions of direct relevance for gallery forest conservation initiatives.

\section{Study area}

\section{Location and environmental settings}

The Gran Sabana is located in the southeast of the CNP, in southeast Venezuela (Figure 1), the second largest protected area in Venezuela, covering $30,000 \mathrm{~km}^{2}$. Geologically, it lies in the Precambrian Guayana Shield that constitutes one of the oldest geological basements in the world (Schubert et al., 1986; Schubert and Huber, 1989), famous worldwide for the presence of some of the most prominent sandstone table mountains (locally called tepuis). The Gran Sabana comprises a plateau with a south-north altitudinal gradient, from 800 to $1500 \mathrm{~m}$ a.s.l. Main parent materials were originated from sedimentary rocks produced along the geological eras by the weathering, leaching, and erosion of the Precambrian basement rocks (Schubert and Huber, 1989), constituted by the ancient sandstones of the Roraima Group, which 
originates very acidic and cation depleted soils, rich in aluminum complexes (Dezzeo, 1994; Fölster, 1994).

The climate is humid submesothermic, with mean annual air temperatures between $17^{\circ} \mathrm{C}$ and $24^{\circ} \mathrm{C}$ and mean annual rainfall around 1600-4000 mm (Dezzeo, 1994; Huber and Febres, 2000). Annual rainfall is unimodal, with a short and slight dry season from January to March, coinciding with the southward migration of the Intertropical Convergence Zone (ITCZ). The altitudinal gradient observed in the region is of ecological significance, leading to differences in climate (air temperatures, total rainfall, and rainfall seasonality) affecting as well the vegetation composition. In fact, such altitudinal differences yield lower mean annual temperatures in the north $\left(17-21^{\circ} \mathrm{C}\right)$ and a more positive dry season soil water balance compared with the south (Huber and Febres, 2000).

\section{Human occupation, fire, and forest degradation}

The Gran Sabana is part of the ancestral lands of the Pemón Amerindians, who belong to the Carib linguistic family (Strauss, 1992). Pemón subsistence is based on slash and burn agriculture and hunting, using fire extensively in all their activities (Kingsbury, 1999, 2001; Rodríguez, 2004). Currently, the occurrence of natural fires in the region is unlikely because of the combination of a low lightning incidence and a humid climate throughout the year (Bilbao et al., 2009). In contrast to the absence of natural fires, human-made fires are started every day in the savannas, burning around 7000 ha annually (EDELCA, 2008).

The reasons the Pemón burn the savannas are reviewed by Rodríguez $(2004,2007)$ and include gaming, pest control, landscape maintenance, and environmental protection, as well as spiritual purposes. Furthermore, the Pemón regard their burning of the landscape as a form of environmental management that promotes forest by maintaining low fuel loads, and thus reduces the risk of accidental fires spreading from the grasslands (Rodríguez and Sletto, 2009).

Most of the times fires are initiated on savannas, are spread to gallery forest-savanna boundaries, and are generally extinguished naturally at the high-humidity forest edges (Leal A, personal observation, 2000-2010). In those cases, fire perhaps does not represent a threat to gallery forests. However, during very dry years (e.g. during El Niño years), forest edges are dry enough to allow the burning of the forest borders, usually killing the trees. The current effect of such degradation is observed mostly in the northern Gran Sabana, where stands of charred trunks immersed in bracken or herbaceous communities occur along savanna-forest transitions (Bilbao et al., 2011), testifying the occurrence of relatively recent fire events and their harmful effect on forest trees. From this, it might be inferred these forest patches were more extensive in the very recent past, implying the occurrence of recent fire-mediated forest retrogression and concomitant expansion of herbaceous communities. The Pemón people attribute these dead stands to drought events in the first half of the last century, which favored catastrophic fire occurrence and spreading (Rodríguez, 2004). However, satellite images and aerial photographs in several areas of the CNP can provide further insights into this issue. These show that in the last 30 years forest loss has occurred only around some overexploited areas close to Pemón villages, while areas away from densely populated localities remain unchanged (Flantua, 2008; Kingsbury, 1999, 2001). Hence, forest degradation is not as accelerated and widespread as governmental stakeholders had supposed and does not appear to be occurring significantly over short (decadal) timescales. This enhances the importance of palaeoecological studies as those that can capture vegetation changes at the timescale they actually occur and allow insights into their causes.

\section{Present vegetation in the Guayana uplands}

Rainforest is the main vegetation cover in the CNP. However, lower rainfall and more acidic soils result in large expanses of treeless savannas in the Gran Sabana area. Here, grasslands are dominated by Trachypogon spicatus and Axonopus anceps (Huber, 1986), representing one-third of plant cover (Delgado et al., 2009).

Another pattern that is important to describe here is the occurrence of disturbance gradients from open treeless savannas to apparently highly disturbed forests, which limits mature tall forests. This has been shown from detailed characterizations of different plant communities (Dezzeo, 1994; Dezzeo and Chacón, 2005). These communities all together create a complex vegetation assortment, spatially arranged in a mosaic-like pattern, with rainforest patchily distributed within extensive grasslands (Figure 1). The gallery forests are also highly fragmented along streams, with interspersed grasslands, fenlands, and scrublands. This mosaic-like arrangement creates an abundance of savannaforest transitions where biomass, biodiversity, and nutrient storage in the vegetation and topsoil decrease as the degree of disturbance increases (Chacón and Dezzeo, 2004, 2007; Dezzeo and Chacón, 2005; Hernández et al., 2012). Also, the fire-drought feedback becomes more positive in more disturbed communities, as has been suggested for other places in the Amazon Basin (Barlow and Peres, 2008).

Regarding the vegetation composition, it is important to underline that Gran Sabana grasslands present some differences with respect to lowland Neotropical savannas. In first instance, the first are predominantly treeless savannas, lacking the shrubby component usually observed in lowland savannas of the Orinoco Llanos, the Brazilian cerrados, and the Rupununi savannas in Guayana (Bilbao et al., 2009). Also, herbaceous legumes and dicots in general are practically absent, and hence, most species from families commonly abundant in lowland Neotropical savannas, such as the Melastomataceae, Asteraceae, and Rubiaceae, are strongly restricted to savanna-forest borders or woody communities. This is of particular importance in this paper since they are considered here as taxa more associated with afterdisturbance forest regeneration than with savanna communities (Bilbao et al., 2011).

Vegetation composition seems to be similar between different forest types, although dominance and structure change according to the degree of disturbance and other features, such as slope, soil quality, and the presence of rivers and streams (Hernández, 1999; Hernández et al., 2012). Members of the Lauraceae family are generally dominant (mainly Ocotea species), as are those of the Fabaceae (Dimorphandra macrostachya, Tachigali guianensis, Alexa sp.), Annonaceae (Anaxagorea sp.), Flacourtiaceae (Eucearea nitida), Chrisobalanaceae (Hirtella sp., Licania sp.), Malpighiaceae (Byrsonima stipulacea), Sapotaceae (Pouteria bangii), Burseraceae (Protium heptaphyllum), among others. It is important to note the lack of pioneer trees and shrubs which are otherwise common at early successional states in other Neotropical forests, as, for example, the Cecropia species. This genus, together with Alchornea, Croton, and other pioneer trees and shrubs, is very scarce or absent in the study area. Hence, the species that grow after disturbance are generally those dominant in the mature forests, together with fast-growing and heliophilic taxa from the Melastomataceae, Rubiaceae, Clusiaceae and Asteraceae families.

\section{Description of the study localities}

Both localities chosen for this study presently comprise herbaceous riversides, where gallery forests are present but discontinuous. Both places are seasonally flooded and swampy riversides, where clayey and organic sediments remain water 
saturated during most of the year. Quebrada Kowana (QK) $\left(990 \mathrm{~m}\right.$ a.s.1., $\left.5^{\circ} 32^{\prime} 45.70^{\prime \prime} \mathrm{N}, 61^{\circ} 44^{\prime} 42^{\prime \prime} \mathrm{W}\right)$ is located in a savanna-forest boundary in the northwestern part of the Gran Sabana, close to the village of Kavanayén (Figure 1), the second most populated town in the Gran Sabana. QK is a creek dissecting a $2.5-\mathrm{km}$-long 1-km-wide savanna patch (Figure 1), dominated by Trachypogon spicatus and Paspalum contractum. This locality lies within a wider rainforest community that has been intensively used for slash and burn agriculture (Kingsbury, 1999, 2001). The core was taken in a small swamp, dominated by Poaceae, Cyperaceae, and Heliconiaceae and surrounded by treeless savannas on well-drained soils.

Ariwe Fernland (AF) (1200m a.s.1.) lies in the vicinities of

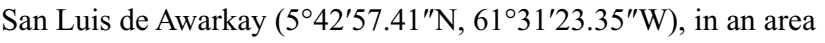
predominantly covered by Trachypogon-Axonopus savannas (Figure 1), about $40 \mathrm{~km}$ from QK. The core was taken in the riverbank of Quebrada Ariwe, a small tributary of Aponwao River. Currently, the riverside is covered by a bracken community (dominated by Pteridium sp.) with a low proportion of woody taxa. Several hundred meters in both directions (upstream and downstream), gallery forest occurs in the Ariwe creek with the characteristic discontinuous-fragmented pattern described above. The core was taken within the bracken community, which in the Guayana uplands used to accumulate high amounts of soil organic matter, mostly in a predominantly clayey soil as that observed in the coring site.

Leal et al. (2013) carried out a study of pollen rain in soils from 30 plant communities in the Gran Sabana. Rainforest and gallery forest were included, as well as small and fragmented forest patches, savanna-forest boundaries, Mauritia palm swamps (morichales), and grasslands. Each plant community was shown to have a distinctive pollen signature. Poaceae pollen was not overrepresented, even in the case of small forest patches surrounded by grasslands. Pollen coming from forest trees was shown to be local-sourced. The ordering of pollen rain samples throughout Principal Component Analysis (PCA) showed that it is possible to attain objective vegetation reconstructions from palynological records and to assess the potential past structure of plant communities along ecological gradients. The analysis of pollen rain samples after Leal et al. (2013) is used to support the QK and AF reconstructions (see the 'Results and interpretation' section and Figure 6 for more details).

\section{Methods}

\section{Sediment sampling and laboratory procedures}

The sediments were taken with a hand-operated Russian corer. An aliquot of $2 \mathrm{~cm}^{3}$ was taken for pollen analysis every $5 \mathrm{~cm}$. Standard methods of acetolysis, removal of silicates, and humic acids were used for sample preparation (Faegri and Iversen, 1981). Lycopodium tablets were added before preparation to estimate pollen concentration (Maher, 1981). Slides to quantify palynomorphs were prepared with a glycerinated gelatin mixture and counted in a light microscope. At least 300 pollen grains of terrestrial taxa were counted. Aquatics, fern spores, fungal and algal spores, and remains were counted apart from the main pollen sum. Pollen was identified using the pollen atlas by Leal et al. (2011). Charcoal was counted in sample relative to the exotic Lycopodium marker. Only the fraction larger than $100 \mu \mathrm{m}$ long was counted, as indicative of local fires (Leal, 2010). At least 100 exotic markers were counted in every level, to ensure representation and results replicability (Fisinger and Tinner, 2005). Samples from cores were selected for $\delta^{13} \mathrm{C}$ analyses and ${ }^{14} \mathrm{C}$ dating and were sent to the GADAM Center in Gliwice, Poland (AF), and to the Erlangen-Nürnberg Institute of Physics in Germany (QK).
Radiocarbon ages were calibrated using Calib 7.01 (by Stuiver and Reimer, available at: http://calib.qub.ac.uk/calib/) and IntCal13 calibration data.

\section{Data analysis and presentation}

Pollen data are presented as percentages of the terrestrial pollen sum including all pollen sourced from terrestrial taxa. Ferns, fungi and algae, and other azonal taxa (as aquatics) abundances were calculated separately. In the Gran Sabana, pollen from generalist families such as the Asteraceae, Melastomataceae, Rubiaceae, undetermined Euphorbiaceae, and undetermined Fabales are strongly restricted to forest communities or savanna-forest borders (see study site description). Furthermore, although these families are able to grow in humid savannas, pollen rain studies by Leal et al. (2013) showed that species belonging to these families are only well represented in savanna/forest borders and forest soils. Hence, in this study, pollen types belonging to the families mentioned above were considered more associated with forest vegetation than with savannas, given the particularities of the study region, and were all pooled in a different ecological group named 'generalist taxa'. Overall, five ecological groups are shown in the pollen diagrams: (1) forest trees and shrubs, (2) understory vegetation and lianas, (3) generalist taxa, (4) savanna herbs, and (5) unknown (undetermined pollen grains). The abundance of each individual taxon and of the five ecological groups was plotted using PSIMPOLL 4.10, PSCOMB 1.04 (by Bennett, Keith). A linear depth/age model was assumed for age extrapolations and interpolations in both records (see Figures 2 and 4). The PCA was used to match modern plant communities with the palynological assemblages found in the sedimentary records (see site description for a summary of main results found by Leal et al., 2013), which was carried out with the software MVSP 3.1.

\section{Results and interpretation}

\section{Stratigraphy and chronology}

QK. A 140-cm-long core was recovered in QK. Stratigraphy is shown in detail in Figure 2. Pollen preservation occurred in the first $120 \mathrm{~cm}$ (Figures 2 and 3), while the deepest $20 \mathrm{~cm}$ (120$140 \mathrm{~cm}$ depth) was barren. Pollen concentrations were about $10,000-40,000$ grains $/ \mathrm{cm}^{3}$. Sub-microscopic charcoal was very abundant, with concentrations between 100,000 and 300,000 particles $/ \mathrm{cm}^{3}$ (Figure 2).

Four radiocarbon dates were obtained (Table 1). An age extrapolation gave a basal age of $3100 \mathrm{cal}$. yr BP (Figure 2). On the other hand, the date obtained for the barren strata was 10,177 cal. yr BP, suggesting the occurrence of a hiatus. This is also supported by the stratigraphical discontinuity between the yellow orange-spotted stratum with the organic strata immediately above (Figure 2). Hence, assuming that probably there is a hiatus in the core with a time gap perhaps of thousands of years, the last date was not taken into account for age/depth extrapolations and interpolations (Figure 2).

AF. A 194-cm-long core was recovered in AF. The core stratigraphy is shown in Figure 4. Pollen preservation occurred throughout the core, with concentrations ranging between 10,000 and 50,000 grains $/ \mathrm{cm}^{3}$. Sub-microscopic charcoal particles were also abundant, with concentrations between 10,000 and 50,000 particles $/ \mathrm{cm}^{3}$ and peaks of more than 100,000 particles $/ \mathrm{cm}^{3}$ (Figure 4 ). Two radiocarbon dates were available (Table 1), showing that sediments were deposited during the late Holocene, with an extrapolated age of around 3400 cal. yr BP (Figure 4). Two distinctive pollen assemblages are observed (Figures 4 and 5). 


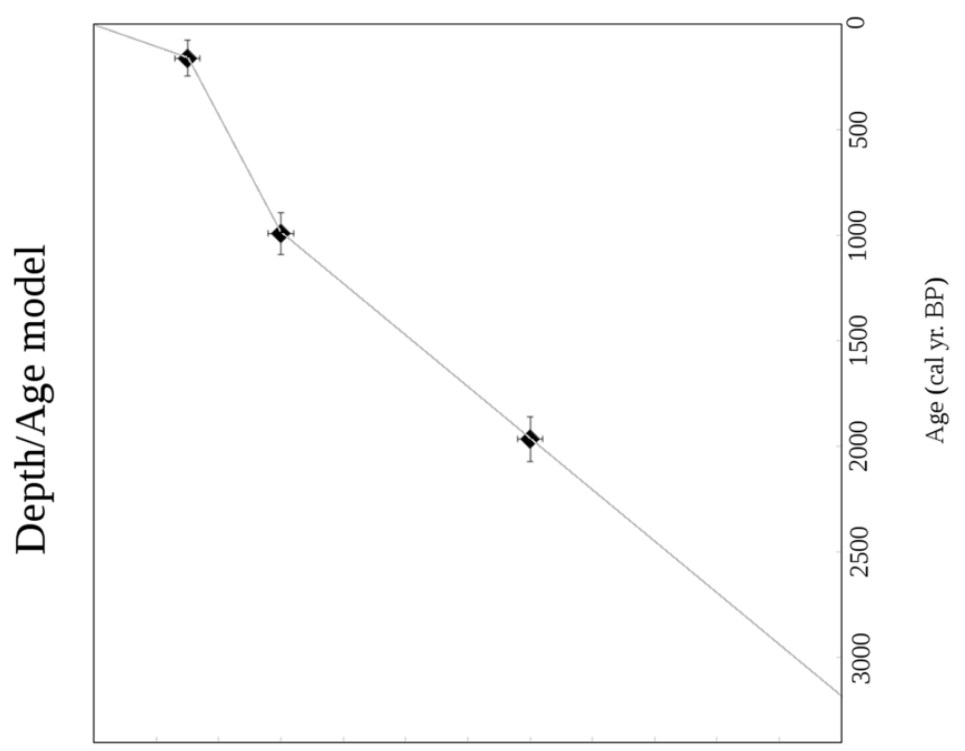

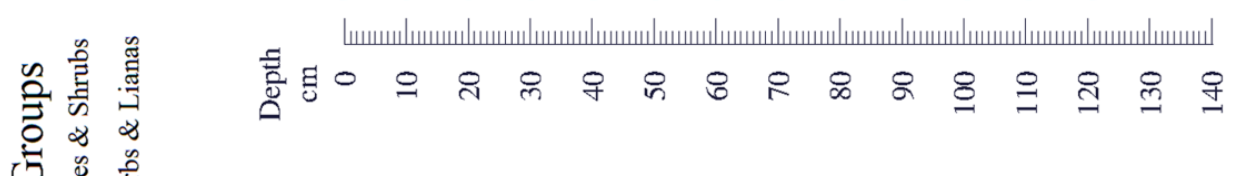

苾产

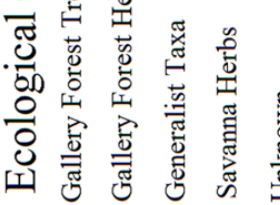
济 $\square \square$
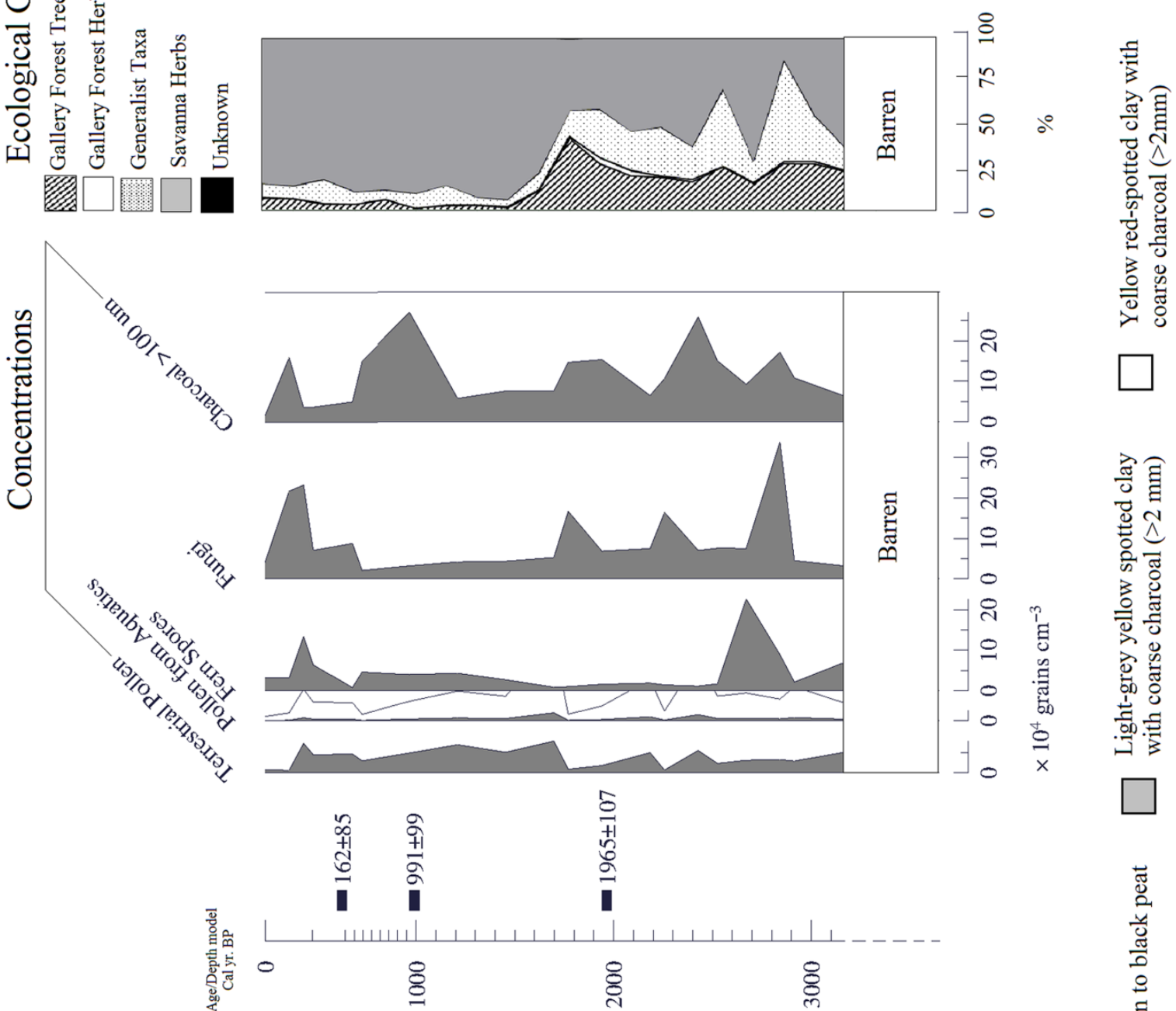

蛋

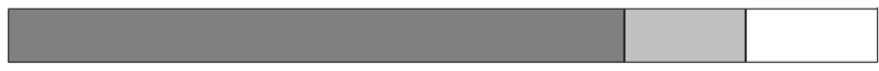

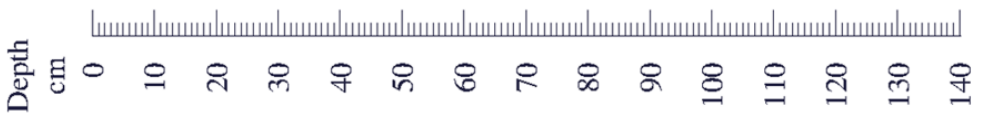

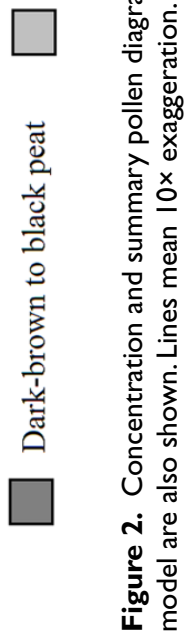




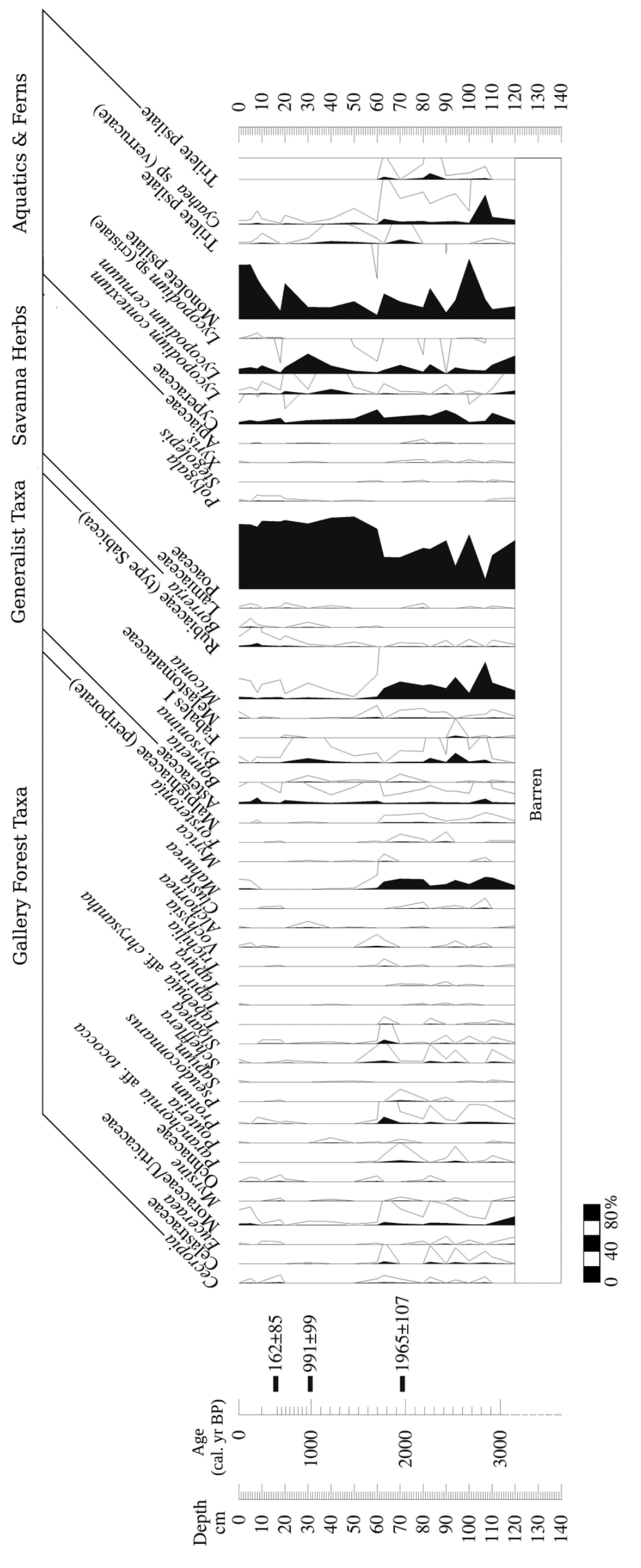




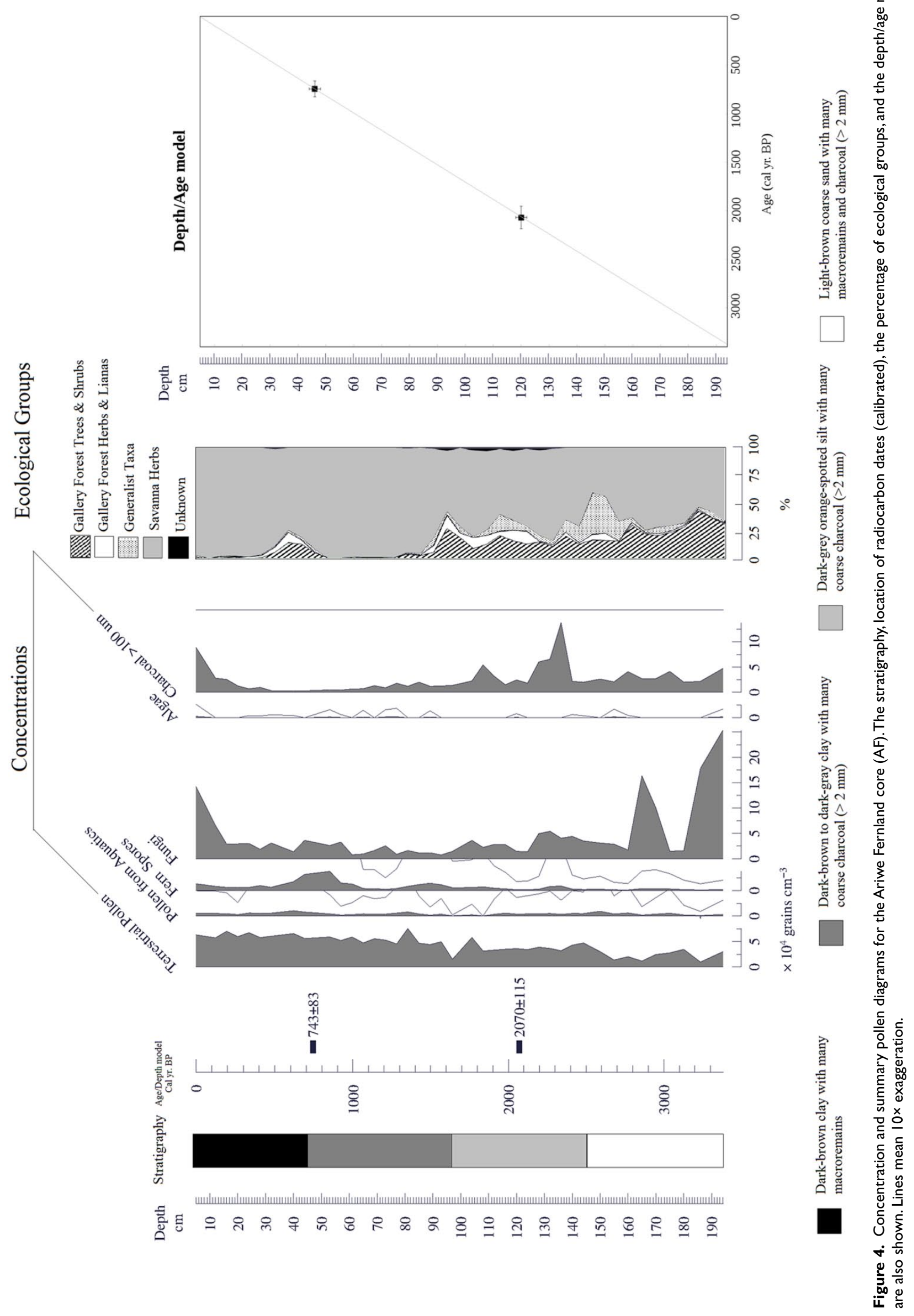


Table I. Radiocarbon dates and calibrated dates (median probability of date ranges) for Ariwe Fernland (AF) and Quebrada Kowana (QK) cores. Laboratory numbers correspond to the GADAM Center (GdA, Gliwice, Poland) and Erlangen-Nürnberg Institute of Physics (Erl, Erlangen, Germany).

\begin{tabular}{|c|c|c|c|c|c|}
\hline Sample & Depth $(\mathrm{cm})$ & Dating material & ${ }^{14} \mathrm{C}$ Date (yr BP) & $\begin{array}{l}\text { Calibrated date } \\
(2 \sigma) \text { (cal. yr BP) }\end{array}$ & Laboratory number \\
\hline AF-46 & 46 & Bulk sediment & $850 \pm 40$ & $743 \pm 83$ & GdA-167I \\
\hline$A F-120$ & 120 & & $2080 \pm 25$ & $2070 \pm 115$ & GdA-1662 \\
\hline QK-15 & 15 & & $110 \pm 40$ & $162 \pm 85$ & Erl-I7497 \\
\hline QK-30 & 30 & & $1060 \pm 40$ & $991 \pm 99$ & Erl-16965 \\
\hline QK-70 & 70 & & $2170 \pm 40$ & $1965 \pm 107$ & Erl-16966 \\
\hline QK-130 & 130 & & $9100 \pm 80$ & $10,177 \pm 204$ & Erl-16967 \\
\hline
\end{tabular}

\section{Description of pollen diagrams and vegetation reconstruction}

QK. Figures 2 and 3 show the concentration and summary diagram and the percentage diagram for QK. Vegetation reconstruction was also based on results from the PCA shown in Figure 6. The main pollen assemblages are described as follows.

From 120 to $65 \mathrm{~cm}(3100-1800$ cal. yr BP), gallery forest taxa fluctuated between $50 \%$ and $30 \%$ of the pollen sum and savanna taxa (mainly Poaceae) were around $50 \%$. Main forest taxa were Moraceae/Urticaceae, Celastraceae, Protium, Schefflera, and Mahurea. The 'generalist taxa' group was very abundant, mainly toward the end of the period, reaching $25 \%$. Cyperaceae and fungi were also high. Charcoal was very abundant, with three maximum values at 2700, 2400, and $1800 \mathrm{cal}$. yr BP.

The above-described pollen assemblage indicates the development of a gallery forest at that time, but the forest was apparently very open and disturbed. This interpretation is supported by the clumping of samples from this period with pollen rain samples taken from small and disturbed forest patches and savanna-forest borders in the PCA (Figure 6). Such a pollen assemblage lacks pollen from tall trees, showing also a high proportion of savanna herbs and pioneer taxa (Figures 2, 3, and 6). This suggests the development of a low-diversity and structurally simple community, similar to the highly fragmented forest patches observed today in the north of Gran Sabana (see Hernández et al. (2012) for a characterization of current gallery forests patches in the study area). The high concentration of charcoal particles suggests the occurrence of recurring fires (Figures 2 and 3), probably the result of fire spreading from neighboring savannas. The effect of local fire occurrence on vegetation can be inferred from Figures 2 and 3 as well, showing the highest abundance of generalist taxa, in coincidence with charcoal concentration peaks (Figures 2 and 3). This suggests the occurrence of after-fire regeneration. A charcoal peak around $65 \mathrm{~cm}$ depth is also concomitant with gallery forest reduction (Figure 2).

On the other hand, the above-described pollen assemblage also implies that the highly disturbed forest inferred for the QK site was apparently surrounded by savannas, as can be inferred from the high percentage of savanna-sourced pollen recorded from the beginning of the sedimentary record (Figures 2 and 3 ). This indicates that such savanna patch is not a result of only recurring late-Holocene fires.

The above-described pollen composition contrasts with that observed from 65 to $0 \mathrm{~cm}$ (1800 yr BP to present) when a strong reduction in gallery forest taxa from $25-50 \%$ to less than $5 \%$ occurred. Savanna herbs increased up to $90 \%$. Cyperaceae, fungal spores, and charcoal decreased notably, mainly from 1600 to 1500 yr BP (65 to $55 \mathrm{~cm}$ depth), and then rose again until the present. From 1500 yr BP to present, some gallery forest taxa disappeared permanently, including Paranchornia, Tabebuia, and Tapura. Charcoal was very abundant throughout this period, with peaks around $1000 \mathrm{yr} \mathrm{BP}$ and during the last two centuries.
The pollen assemblage from 1800 to 1600 cal. yr BP to present suggests that the gallery forest was degraded and substituted by a herbaceous community, which occupies the site today. Again, this interpretation is supported by the ordination of most recent samples of QK together with pollen rain samples taken in living herbaceous communities (Figure 6), as well as by sedimentary ${ }^{13} \mathrm{C}$ ratios (Table 2), which show a clear transition from lower to higher delta values implying the progressive replacement of plants using the $\mathrm{C} 3$ photosynthetic pathway in the deepest (older) half of the record, by grasses utilizing $\mathrm{C} 4$ photosynthesis, in the uppermost (youngest) half of the record (Table 2). In the Gran Sabana, C3 plants are strongly restricted to forests and savannaforest borders (Bilbao et al., 2011); hence, the increase in the $\delta^{13} \mathrm{C}$ ratio of soil organic carbon (SOC) observed from $70 \mathrm{~cm}$ indicates the expansion of savannas at expense of forests. In addition, the high charcoal concentrations imply that this forest degradation was mediated by fire. Possibly, a feedback between a drier climate and a higher fire frequency contributed to this degradation of gallery forest. Indeed, drier conditions around $1800 \mathrm{yr}$ BP are inferred from the drop of aquatics (mainly Cyperaceae) and fungal spores.

Another important aspect is the assessment of the possible origin of palaeofires in the study area. QK lies in a savanna patch immersed in a predominantly forested area; hence the presence of a continuous charcoal record is difficult to explain without considering cultural burning as the main ignition source. The lateHolocene age of this record also suggests the anthropogenic character of fires, since this phase was contemporaneous with the intensification of human occupation in the Orinoco (Gassón, 2002; Strauss, 1992) and Amazon Basins (Bush et al., 2014; Clement et al., 2015; Piperno et al., 2015; Urrego et al., 2013). Therefore, cultural burning was potentially the main cause of fires in the study area during the period encompassed.

AF. The pollen diagrams for AF are shown in Figures 4 and 5 . Interpretation is also based on the PCA of Figure 6. Main pollen assemblages are described as follows.

From 194 to $94 \mathrm{~cm}(3400-1600$ yr BP), gallery forest taxa reached $35-40 \%$ of the terrestrial pollen sum and savanna herbs (mainly Poaceae) represented 40-60\%. The most abundant gallery forest taxa are Astronium, Dimorphandra, Moraceae/Urticaceae, Pourouma, Protium, Schefflera, Tachigali, and Blepharandra. The greatest abundance of generalist taxa was also observed (i.e. Miconia and other Melastomataceae). Aquatics and fungi also show a high abundance. Charcoal concentrations were very high, with two maximum values around 2200 and $1800 \mathrm{cal}$. yr BP. These coincide with the lowest values of algal remains.

The occurrence of a former open and disturbed gallery forest from 3400 to $1600 \mathrm{cal}$. yr BP is inferred and supported by the pollen assemblage, as well as by the good correspondence of pollen assemblages in these samples with pollen rain samples from savanna-forest borders (Leal et al., 2013; Figure 6). However, a 


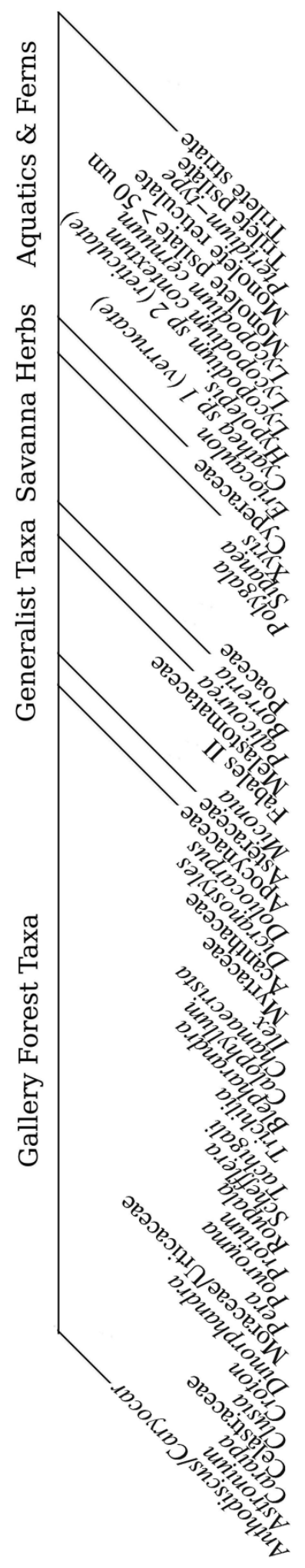

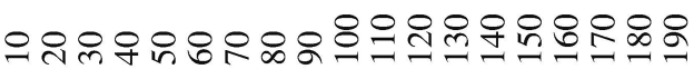
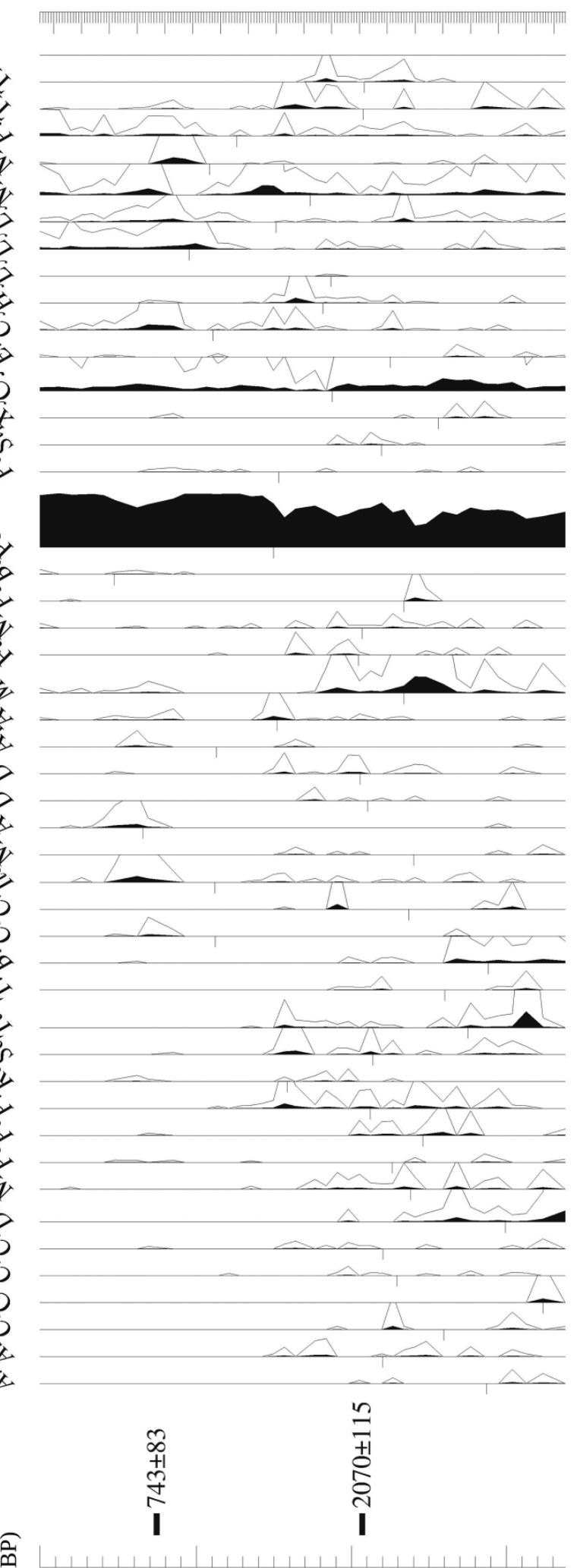

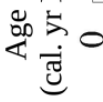

ริ)

ఠ̊

ఠ

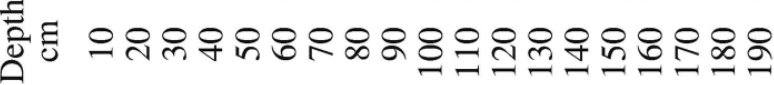




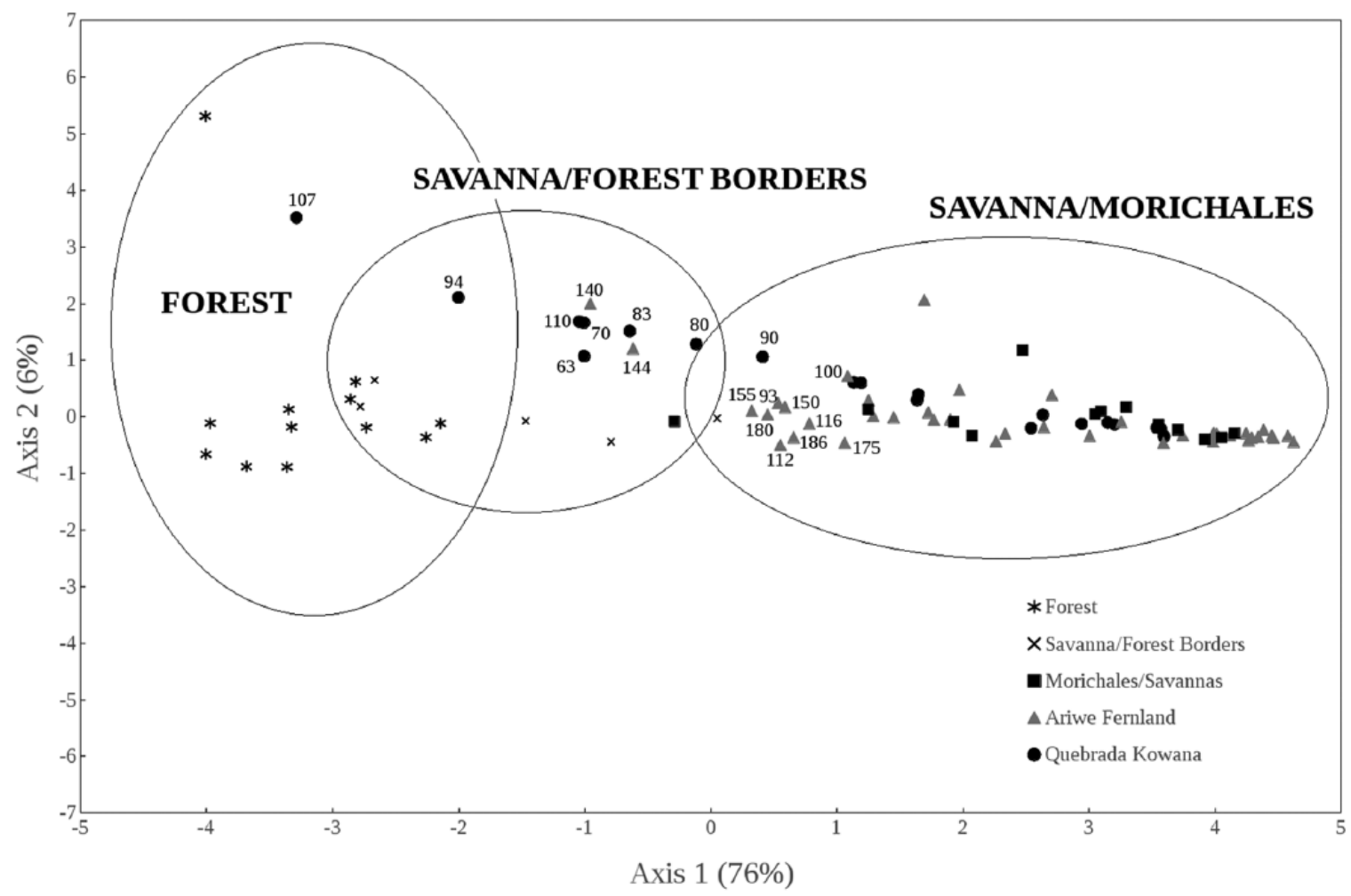

Figure 6. Principal Component Analysis (PCA) of pollen rain samples in forests, savanna-forest borders, savannas, and morichales (i.e. Mauritia palm swamps) (after Leal et al., 20I3), together with samples from Quebrada Kowana (QK) and Ariwe Fernland (AF) cores. The percentage of data variance explained by every axis is shown between parentheses. Deepest samples of every core are ordered together with modern pollen rain samples of savanna-forest borders, while upper samples are ordered with those from open herbaceous communities. Some points were labeled to show the depth (in centimeters) at which they correspond. See the text for more details.

Table 2. Stable carbon isotopic ratios in the soil organic carbon (SOC) of Quebrada Kowana (QK) core.

\begin{tabular}{lcc}
\hline Sample & Depth $(\mathrm{cm})$ & $\delta^{13} \mathrm{C}$ \\
\hline 1 & 15 & -19.4 \\
2 & 30 & -18.6 \\
3 & 42 & -20.1 \\
4 & 70 & -20.2 \\
5 & 86 & -26.3 \\
6 & 115 & -27.8 \\
7 & 120 & -26.3 \\
\hline
\end{tabular}

gradual modification of forest composition is indicated by the impoverishment in pollen from woody taxa (Figure 5). In fact, at the beginning of the sequence, pollen from Dimorphandra was abundant. This is a canopy tree very common in forests above $1000 \mathrm{~m}$ a.s.1., with a potential height of $30 \mathrm{~m}$. Subsequently, together with others from tall canopy trees (i.e. Anthodiscus, Protium), these taxa progressively diminished in abundance and were substituted by shrubby pioneer taxa such as Schefflera and Miconia (Figure 5). This process of diversity loss was coupled with high charcoal concentrations, implying the recurrent burning of gallery forest and the regeneration after fire, predominantly by shrubby fast-growing heliophilic taxa. This suggests a cumulative effect of fire on vegetation, throughout the subsequent modification of composition/structure, after successive fire events.

From 94 to $0 \mathrm{~cm}(1600 \mathrm{cal}$. yr BP to present day), pollen of gallery forest taxa decreased to less than $5 \%$ and savanna herbs reached $95 \%$ or more. Fern spores increased, mainly Pteridium, Lycopodium and Cyathea (verrucate type). Pollen richness decreased strongly, and many gallery forest taxa disappeared permanently, for example, Anthodiscus/Caryocar, Astronium, Caraipa, Celastraceae, Clusia, Croton, Dimorphandra, Protium,
Tachigali, and Trichilia. Around $600 \mathrm{cal}$. yr BP (38 cm depth), a raise of gallery forest and generalist taxa from less than 5-25\% was recorded, with the increase in Croton, Pera, Pourouma, Roupala, Blepharandra, Calophyllum, Ilex, Acanthaceae, Doliocarpus, and Apocynaceae, together with Asteraceae and Miconia. Charcoal was reduced, but from 600 cal. yr BP to present, savanna herbs reached more than $95 \%$ of the terrestrial pollen sum, and charcoal similarly rose in a sustained way.

This pollen assemblage suggests the complete substitution of gallery forests by grasslands in AF from $\sim 1600$ cal. yr BP (Figures 4 and 5). The increase in fern spores, mainly from Lycopodium species and also from Pteridium, can be interpreted as the local development of a bracken community. This situation was maintained until $\sim 600 \mathrm{cal}$. yr BP, where a pulse of woody regeneration occurred, coincident with the lowest charcoal abundance (Figure 4). This pulse was, however, ephemeral and the dominance of savanna herbs was quickly re-established, remaining until today. In AF, forest degradation was apparently triggered by droughts/fires feedbacks, as it was in QK. In fact, forest reduction was coupled with a decrease in aquatics, fungal, and algal remains (Figures 4 and 5), suggesting a less positive soil water balance than before in the study site.

Regarding the possible origin of palaeofires occurring in $\mathrm{AF}$, it is important to point out that the study site lies in a savanna-dominated area. Hence, the occurrence of non-human-made fires cannot be discarded. Nevertheless, it was explained that currently these fires are very unlikely to happen, and therefore, it is proposed that anthropogenic burning was the main source of fires in $\mathrm{AF}$, as it was actually in QK.

\section{Additional comments about the interpretation of charcoal abundances and palaeofire reconstruction}

It is widely recognized that palaeofire reconstruction using sedimentary charcoal is very difficult to achieve (see Clark, 1988; 
MacDonald et al., 1991; Patterson et al., 1987). Two main components of charcoal signal are the charcoal fractionation and the absolute abundance of every charcoal size. Both parameters are the product of very complex and strongly non-linear functions, where many factors contribute, among others: the fuel load characteristics, the fire behavior variables, the meteorological variables, the nature of the catchment basins under study, and the transport, depositional, and taphonomic processes (Clark and Royall, 1995; Kangur, 2002). The above-mentioned variables together with the fire regimes and sedimentation rates determine the absolute abundance of charcoal in every sedimentary level, a parameter that usually researchers seek to correlate directly with regional and local fire frequencies (MacDonald, 1996). However, even in high-resolution studies carried out in the Northern Hemisphere, it has been difficult to correlate actual fire frequencies with abundance peaks of charcoal counted in pollen slides (Gardner and Whitlock, 2001; MacDonald et al., 1991; Tinner et al., 1998, 1999).

In the Neotropics, the interpretation of charcoal abundances in sedimentary records could be even more difficult, since modern charcoal production/deposition studies available are very scarce. In the Gran Sabana, a study on charcoal abundance patterns in topsoils of burnt and unburnt communities was carried out by Leal (2010). This showed that the presence of charcoal particles $>100 \mu \mathrm{m}$ length in pollen slides is a confident indicator of the occurrence of local fires in the past. In general terms, it was observed that communities with higher aboveground biomass tend to accumulate more charcoal than communities with lower fuel loads. Hence, biomass seems to contribute more to charcoal signal magnitudes than fire frequencies.

Therefore, given the inherent complexity within the charcoal signal, what conclusions can be obtained from the charcoal records presented here? By one side, it is possible to infer with a high degree of confidence that local fires actually occurred at both study places, in a continued fashion during the whole time encompassed. The higher charcoal accumulation in the forest-dominated part of every record is indeed an independent evidence that supports that fires were reaching the gallery forests, since a higher charcoal accumulation is expected as a product of forest burning than from savanna burning.

Additionally, both records exhibit concomitant changes in vegetation and charcoal abundances, suggesting the occurrence of firevegetation feedbacks. In the case of $\mathrm{QK}$, changes on forest composition after recurring fires (mainly the rise of fast-growing heliophilic taxa) as well as a charcoal peak associated with forest retrogression were observed (Figures 2 and 3). Regarding the AF record, a process of gradual impoverishment of pollen from canopy trees was recorded (Figures 4 and 5), pointing out an after-disturbance vegetation response. This suggests a sort of cumulative effect of fire on vegetation, where recurring fires are triggering compositional changes, reducing diversity and vertical complexity. Such kind of positive feedbacks between fire and vegetation is broadly documented in Neotropical rainforest (see Barlow and Peres, 2008), where the substitution of mature and structurally complex forest by a shrubby secondary regeneration led to change in critical microclimatic condition (as, for example, insolation and topsoil humidity, etc.). The aboveground biomass of such disturbed forests is also more susceptible to desiccation, leading to increased fuel loads, favoring the spreading of fire from savannas into forests.

\section{Discussion}

\section{Gallery forest degradation in the Gran Sabana}

Results presented here show the late-Holocene replacement of gallery forest by herbaceous communities at both sites studied. This forest retrogression was irreversible and happened almost simultaneously, at $\sim 1800 \mathrm{yr} \mathrm{BP}$ in $\mathrm{QK}$ and $1600 \mathrm{yr} \mathrm{BP}$ in AF. Given the precision associated with calibrated radiocarbon ages and the depth/age interpolations, this is considered broadly simultaneous at both sites.

The former gallery forests evidenced at the beginning of both records are palynologically analogous to structurally simple and low-diversity modern forests (Figure 6), indicating that ancient forests in QK and AF were probably already highly disturbed when the sedimentary record began. This has important implications for forests conservation in the Gran Sabana, indicating that current gallery forests might be remnants of a long-term continuous fragmentation, which operates at a regional scale (as it is also supported by Hernández et al., 2012). Furthermore, the results support findings of late-Holocene forest degradation process elsewhere (Montoya and Rull, 2011; Rull et al., 2012, 2015), implying a regional-scale phenomenon, which has been happening on both the alluvial plains of the southern Gran Sabana and in its northern part.

The continuous accumulation of charcoal is observed in several late-Holocene pollen records studied in the area (Leal, 2010; Leal et al., 2013; Montoya and Rull, 2011; Rull, 1999), and this is confirmed at the study sites here, implying a high incidence of fires during the last 3000 years at the regional scale. Fires were most likely human-made, and potentially fire spread from neighboring savannas. Our findings also agree with previous Palaeoecological studies in demonstrating the detrimental effect of recurring fires on gallery forests. In fact, the results indicate that the forests were degraded as a result of recurrent burning in both cases, mainly throughout fire-mediated compositional changes. We hypothesized that the fire-mediated modification of forest composition/structure constitutes a cumulative effect, which favors at the end the irreversible forest degradation. However, it is important to highlight that in both records presented here, only the combination of local fires with severe droughts caused the final substitution of gallery forest by savannas, supporting that fire nature and its damaging effect on vegetation were in both study places highly controlled by climate. This conclusion also arose in prior studies (see Rull et al., 2012, 2015).

\section{Comparison with other savanna records in northern South America}

The northern limits of the Roraima savannas in Brazil lie adjacent to the Gran Sabana and have comparable edaphic characteristics and vegetation compositions. These savannas are also not considered to be in equilibrium with current climate (Meneses et al., 2015). One of the first studies that documented the late-Holocene expansion of savannas at expense of forest in Roraima was that of Desjardins et al. (1996) who studied the $\delta^{13} \mathrm{C}$ of SOC in cores taken along transects in savanna-forest boundaries. Charcoal pieces from wood found in the studied records suggested that fire contributed with the vegetation changes observed. A more complex picture was recently presented by Meneses et al. (2015) in the same region, where three late-Holocene Palaeoecological records exhibited different trends: forest reduction in one place and more stable forest/palm swamp patches in the others. These findings stress the role of human-made fires in shaping savanna/ palm swamps/forest mosaics, but also point out the importance of the extremely poor, acidic soils present in the region, and local edaphic and microclimatic variations, as significant controls on the current vegetation patterns.

In the savannas of Rupununi (Guayana), the only record with radiocarbon dates is from Lake Moriru (Wijmstra and van der Hammen, 1966). As pointed out by Behling and Hooghiemstra (2001), Rupununi and Roraima savannas are parts of the same grassland system. There, the expansion of savannas and the subsequent forest reduction from 3000 cal. yr BP to present are also documented. No charcoal record was recovered and the potential role of fire and late-Holocene human activities in the area is not possible to assess. 
In other savanna areas of northern South America, as in the Orinoco savannas, a high heterogeneity of responses to external disturbances (climate change and fire) exists as well, although in general terms gallery forests have experienced a marked expansion during the last 4000-3000 years (Behling and Hooghiemstra, 2001; Berrío et al., 2000). This was recorded even in places where charcoal influx increased (Leal and Bilbao, 2011), suggesting that multiple interacting factors need to be considered to explain different vegetation responses to similar external disturbances.

\section{Cultural burning in the Gran Sabana:A long-term process?}

Continuous palaeofire records found in the Gran Sabana, even during the wettest periods of the Holocene, are difficult to explain without considering an anthropogenic source of ignition. In fact, this observation has been used as the basis of a proposed early human occupation of the area (Montoya and Rull, 2011; Rull, 2009). This fact has not been demonstrated, however, since archaeological evidence is needed to support such a conclusion, and unfortunately, archaeological studies are lacking in the CNP. The possibility of non-anthropogenic sources of ignition taking place in the region since the early to mid-Holocene therefore remains open. Despite this, and given the knowledge about the nature and extension of human occupation in the Orinoco Basin during the last 3000 years (Clement et al., 2015; Gassón, 2002; Strauss, 1992), cultural burning as a major source of fires during the late-Holocene remains highly plausible, and the presently available Palaeoecological evidence implies that human-made fires played an important role in the landscape configuration of the Gran Sabana during at least the last 3000 years (and probably earlier). This contributed to the mosaic of fire-sensitive (rainforest) and fire-prone (savannas) ecosystems that currently dominate the area. If the Gran Sabana is a cultural landscape, then the conservation target also should be rethought, since not only the conservation of biological diversity is important but also the conservation of the cultural diversity.

The question remains, who has been burning the Gran Sabana? There has been great speculation about the time of arrival of Pemón people at the CNP (Rodríguez, 2004; Rull, 2009), but no empirical evidence exists at this respect. The Pemón are linguistically affiliated to the Carib-group, whose origin and complex spread along South America are not well understood (Strauss, 1992). In addition, complex changes in the socio-political boundaries between Amerindian groups occurred after the European conquest. Thus, artificial and arbitrary linking between ancient and current fire practices in the CNP should be done cautiously. Nevertheless, inferences from Palaeoecological studies are still very useful in complementing and informing current fire practices and policy making, within an open intercultural framework.

\section{Linking palaeoecology and ecology: Implications for fire management in the CNP}

Palaeoecological studies have provided important insights to assess the status of living forests communities and the role of fire in their configuration (see Leal, 2010; Montoya et al., 2011a, 2011b, 2011c; Montoya and Rull, 2011; Rull et al., 2012, 2015). Key conclusions from such data are as follows: (1) extensive savannas in the southeast of CNP have existed since the early Holocene and are not a product of recent short-term indigenous peoples' activities; (2) fire is not a novel disturbing force in the area, but on the contrary, it has been present since at least the Pleistocene/Holocene boundary; (3) fire is essential to maintain grasslands and has played a key role in the substitution of forest by savannas in some localities, through complex climate-fire feedbacks; (4) cultural burning was very likely the main source of fires during the Holocene (with a great degree of confidence, it was during the late Holocene), but climate has probably moderated fire severity and its final effect on vegetation.

What are the repercussions of such conclusions for the current management of Gran Sabana landscape? The above conclusions suggest that the spatially complex vegetation assortment observed in the Gran Sabana was historically shaped. Hence, positive feedbacks between fire, droughts, and vegetation have been taking place in the area along thousands of years. Therefore, potential consequences and effects of fire prevention should be considered. In this respect, it might be argued that burning prevention will actually lead to increased fuel loads, mainly in the savanna-forest transitions, where wetter conditions and higher soil fertility enhance biomass production (Bilbao et al., 2009). If accidental fires cannot be avoided, the risk of catastrophic wildfires will increase, and fire will spread more widely. In fact, these positive fire/vegetation feedbacks have already been documented for the Amazon Basin in stand-up modern forests (Cochrane and Barber, 2008; Dube, 2009; Hoffmann et al., 2002; Monteiro et al., 2014; Nepstad et al., 1999, 2001).

Additionally, it should be asked, 'Is it actually possible to keep fire out of the CNP?' It seems the answer is no, since today more than 30,000 people are living inside the CNP boundaries, using fire intensively and every day in the area. Rodríguez (2004), Sletto (2008), and Sletto and Rodríguez (2013) have proposed that many of the catastrophic fires that occurred during the last century were the product of landscape abandonment, as a consequence of social and cultural changes promoted by modernity. Some studies of current distribution of fire foci support this, as nowadays burning practices occur in a $5-10 \mathrm{~km}$ radius from Pemón settlements (Ablan et al., 2005). As a result, extensive areas of unmanaged savannas have been accumulating fuel along the years (Sletto, 2008), a pattern that could be correlated with the increase of catastrophic wildfires in the last decades.

In the current context of Global Warming, where a higher frequency of extreme climatic events is expected for the Venezuelan Guayana (Martelo, 2004), the management of risks associated with climate and wildfires has to be urgently addressed in order to avoid biodiversity loss (Hirota et al., 2010). A simplistic model of fire exclusion might fail, having detrimental impacts, not only in terms of forest conservation, as was discussed above, but also upon the ancestral fire practices, that are being lost quickly, after the implementation of inadequate policies in the park (Bilbao et al., 2009, 2010; Rodríguez, 2004, 2007; Rodríguez and Sletto, 2009). These kinds of conclusions have not only arisen in the CNP but also in other protected areas, where the management of wildfire risk is focused in novel approaches that take into consideration the traditional knowledge bodies (Bloesch, 1999; Colding et al., 2002; du Toit et al., 2004; McGregor et al., 2010). For the CNP, the implementation of a system of Patch Mosaic Burning (PMB) has been suggested - a technique that prevents fuel accumulation in savannas, avoiding wildfires spreading into forested areas. Fire experiments in the Gran Sabana have shown that it is possible to apply the PMB system in a regional scale, based in the Amerindian knowledge that also constitutes the base of the cooperative burning of savannas (Bilbao et al., 2010). Such an approach might help to tackle the fire problem in the CNP, but must be accompanied by analyses of ecological, social, and institutional vulnerability and resilience over the long, medium, and short terms, in order to guarantee success (Millán, 2015).

\section{Conclusion}

Results presented here show the replacement of gallery forests by grasslands during the late-Holocene in the north of Gran Sabana. This process was mediated by climate-fire interactions. The continuous accumulation of coarse submicroscopic charcoal in the 
records presented here, and in several late-Holocene pollen records available for the area, suggests a high regional fire incidence during the last 3000 years, whose severity and final effect on vegetation are moderated by climate. Most likely, late-Holocene palaeofires in the area were predominantly human-made.

The former gallery forests present at the beginning of the records shown here are palynologically analogous to very open, structurally simple, and low-diversity stand-up living forests, which could have had a very long previous disturbance history. This conclusion has important implications for the conservation of woody communities in the savanna uplands, since it indicates that they are remnants of a historical fragmentation process that probably have modified the resilience levels of these communities.

Since human-made fires have apparently contributed to the configuration of the vegetation mosaic currently observed, the rethinking of the Gran Sabana as a cultural landscape is proposed. Hence, the conservation target should be completely rethought as well, since not only is the integrity of biological diversity important but also the conservation of biodiversity in the broad sense, including the cultural diversity.

In light of results presented here, complementation of the Pemón's fire practices is recommended, with discourse between indigenous people, scholars, and governmental institutions important in the identification of a means to achieve fire risk management in a Global Warming scenario.

\section{Acknowledgements}

Thanks to Estación Científica Parupa, mainly to María Eugenia Deza, Ruben Machuca (deceased), Francisco Perez, Milagro Marquez, and Humberto Chani, and to Adriana Millán and Ruth Salazar, for fieldwork assistance. Thanks to Iokiñe Rodríguez, Vivian Jeske, Valentí Rull, and an anonymous referee for critical comments and suggestions that helped to improve the manuscript. Thanks to Alfredo Sanson for English style suggestions.

\section{Funding}

The authors acknowledge the financial support given by Decanato de Investigación y Desarrollo of Universidad Simón Bolívar (DID-USB): Grant S1-N1 on behalf of Alejandra Leal, as well as Fondo Nacional para la Ciencia y Tecnología (FONACIT), Grant 2011000404.

\section{References}

Ablan M, Dávila M, Hoeger H et al. (2005) Modeling fire risk: The upper Caroní watershed case. In: Proceedings of the IASTED International Conference on Applied Modeling and Simulation, Oranjestad, 29-31 August 2005.

Barlow J and Peres C (2008) Fire-mediated dieback and compositional cascade in an Amazonian forest. Philosophical Transactions of the Royal Society 363: 1787-1794.

Behling H and Hooghiemstra H (2001) Neotropical savanna environments in space and time. In: Markgraf V (ed.) InterHemispheric Climate Linkages. London: Academic Press, pp. 307-323.

Berrío J, Hooghiemtra H, Behling $\mathrm{H}$ et al. (2000) LateHolocene history of savanna gallery forest from Carimagua area, Colombia. Review of Palaeobotany and Palynology 111: 295-308.

Bilbao B, Leal A and Mendez C (2010) Indigenous use of fire and forest loss in Canaima National Park, Venezuela: Assessment and tools for alternative strategies of fire management in Pemón indigenous lands. Human Ecology 38: 663-673.

Bilbao B, Leal A, Méndez C et al. (2009) The role of fire in the vegetation dynamics of upland savannas of the Venezuelan Guayana. In: Cochrane M (ed.) Tropical Fire Ecology: Climate Change, Land Use and Ecosystem Dynamics. Berlin: Springer-Praxis, pp. 451-461.
Bilbao B, Leal A, Méndez C et al. (2011) Significado ecológico de las sabanas y zonas de transición sabana-bosque en el mosaico de vegetación de la Gran Sabana. Recomendaciones para el manejo y la recuperación de áreas degradadas por el fuego. In: Herrera F and Herrera I (eds) Experiencias de Restauración Ecológica en Venezuela. Caracas: Ediciones IVIC, pp. 97-122.

Bloesch U (1999) Fire as a tool in the management of a savanna/ dry forest reserve in Madagascar. Applied Vegetation Science 2: $117-124$.

Bush M, McMichael C, Raczka M et al. (2014) The Holocene of the Amazon. In: de Souza Carvalho I, Garcia MJ, Lana CC et al. (eds) Paleontología: Cenários de Vida-Paleoclimas. Rio de Janeiro: Editora Interciência, pp. 369-385.

Chacón N and Dezzeo N (2004) Phosphorus fractions and sorption processes in soil samples taken in a forest-savanna sequence of the Gran Sabana in southern Venezuela. Biological Fertility of Soils 40: 14-19.

Chacón N and Dezzeo N (2007) Litter decomposition in primary forest and adjacent fire-disturbed forests in the Gran Sabana, southern Venezuela. Biological Fertility of Soils 43: 815-821.

Clark J (1988) Particle motion and theory of charcoal analysis: Source area, transport, deposition and sampling. Quaternary Research 30: 67-80.

Clark J and Royall D (1995) Particle size evidence for source areas of charcoal accumulation in the Late-Holocene sediments of eastern North American lakes. Quaternary Research 43: 80-89.

Clement C, Denevan W, Heckenberger M et al. (2015) The domestication of Amazonia before European conquest. Proceedings of the Royal Society B: Biological Sciences 282. Available at: http://dx.doi.org/10.1098/rspb.2015.0813.

Cochrane $\mathrm{M}$ and Barber C (2008) Climate change, human land use and future fires in the Amazon. Global Change Biology 15: 601-612.

Colding J, Elmquist T and Olsson P (2002) Living with disturbance: Building resilience in social-ecological systems. In: Berkes F, Colding J and Folke C (eds) Navigating SocialEcological Systems. London: Cambridge University Press, pp. 163-185.

Delgado L, Castellanos H and Rodríguez M (2009) Capítulo 2: La Vegetación. In: Celsa Señaris J, Lew D and Lasso C (eds) Biodiversidad del Parque Nacional Canaima. Caracas: The Nature Conservancy, pp. 39-73.

Desjardins T, Carneiro Filho A, Mariotti A et al. (1996) Changes of the forest-savanna boundary in Brazilian Amazonia during the Holocene revealed by stable isotope ratios of soil organic carbon. Oecologia 108: 749-756.

Dezzeo N (1994) Ecología de la altiplanicie de la Gran Sabana (Guayana Venezolana) I. Scientia Guaianae 4: 1-205.

Dezzeo N and Chacón N (2005) Carbon nutrients loss in aboveground biomass along fire induced forest-savanna gradient in the Gran Sabana, Venezuela. Ecology and Management 209: 343-352.

du Toit J, Walker B and Campbell B (2004) Conserving tropical nature: Current challenges for ecologists. Trends in Ecology and Evolution 19: 12-17.

Dube O (2009) Linking fire and climate: Interactions with land use, vegetation, and soil. Current Opinion in Environmental Sustainability 1: 161-169.

Electrificación del Caroní (EDELCA) (2008) La Cuenca del Río Caroni en Cifras. Puerto Ordáz: EDELCA.

Faegri K and Iversen J (1981) Textbook of Pollen Analysis. 3rd Edition. New York: Hafner Publishing.

Fisinger W and Tinner W (2005) Minimum counts sums for charcoal-concentration estimates in pollen slides: Accuracy and potential errors. The Holocene 15: 293-297. 
Flantua S (2008) Land use and land cover change in the Sector II, Kamarata of the Canaima National Park, Venezuela. Master Thesis, University of Amsterdam.

Fölster H (1994) Stability of forest ecosystems in the humid tropics. Interciencia 19: 291-296.

Gardner J and Whitlock C (2001) Charcoal accumulation following a recent fire in the Cascade Range, northwestern USA, and its relevance for fire-history studies. The Holocene 11(5): 541-549.

Gassón R (2002) Orinoquia: The archaeology of the Orinoco River Basin. Journal of World Prehistory 16: 237-311.

Hernández L (1999) Ecología de la altiplanicie de la Gran Sabana (Guayana Venezolana) II. Scientia Guaianae 9: 1-185.

Hernández L, Delgado L, Meier W et al. (2012) Empobrecimiento de bosques fragmentados en el norte de la Gran Sabana, Venezuela. Interciencia 37: 891-908.

Hirota M, Nobre C, Daisuke M et al. (2010) The climatic sensitivity of the forest, savanna and forest-savanna transition in tropical South America. New Phytologist 187: 707-719.

Hoffmann W, Schroeder W and Jackson R (2002) Positive feedbacks of fire, climate and vegetation and the conversion of tropical savanna. Geophysical Research Letters 29: 1-4.

Huber O (1986) La vegetación del la Cuenca del Río Caroní. Interciencia 11: 301-310.

Huber O and Febres G (2000) Guía Ecológica de la Gran Sabana. Caracas: The Nature Conservancy.

Kangur M (2002) Methodological and practical aspects of the presentation and interpretation of microscopic charcoal data from lake sediments. Vegetation History and Archaeobotany 11: 289-294.

Kingsbury N (1999) Increasing pressure on decreasing resources: A case study of Pemón Amerindian shifting cultivation in the Gran Sabana, Venezuela. PhD Thesis, York University.

Kingsbury N (2001) Impacts of land use and cultural change in a fragile environment: Indigenous acculturation and deforestation in Kavanayén, Gran Sabana, Venezuela. Interciencia 26: 327-336.

Leal A (2010) Historia holocena de la vegetación y el fuego en bordes sabana-bosque y turberas de la Gran Sabana, Guayana Venezolana. PhD Thesis, Universidad Simón Bolívar.

Leal A and Bilbao B (2011) Cambios de vegetación durante el Holoceno tardío en un morichal de los Llanos del Orinoco, Venezuela. Acta Botanica Venezuelica 34: 237-256.

Leal A, Berrío J, Raimundez E et al. (2011) A pollen atlas of premontane woody and herbaceous communities from the upland savannas of Guayana, Venezuela. Palynology 25: 226-266.

Leal A, Bilbao B and Berrío J (2013) A Contribution to pollen rain characterization in forest-savanna mosaics of the Venezuelan Guayana and its use in vegetation reconstructions from sedimentary records. American Journal of Plant Sciences 4(7A): $33-52$.

MacDonald GM (1996) Non-aquatic Quaternary. In: Jansonius J and McGregor D (eds) Palynology: Principles and Applications, vol. 2. Salt Lake City, UT: AASP Foundation, pp. 879-910.

MacDonald GM, Larsen C, Szeicz J et al. (1991) The reconstruction of boreal forest fire history from lake sediments: A comparison of charcoal, pollen, sedimentological, and geochemical indices. Quaternary Science Reviews 10: 53-71.

McGregor S, Lawson V, Cristophersen P et al. (2010) Indigenous wetland burning: Conserving natural and cultural resources in Australia's World Heritage-listed Kakadu National Park. Human Ecology 38: 721-729.

Maher L (1981) Statistics for microfossils concentration measurements employing samples spiked with marked grains. Review of Palaeobotany and Palynology 32: 153-191.

Martelo M (2004) Primera Comunicación Nacional en Cambio Climático de Venezuela. Proyecto MARN-PNUD VEN/00/
G31. Caracas: Dirección de Hidrología, Meteorología y Oceanología-Dirección General de Cuencas HidrográficasMARN.

Meneses M, Costa M, Enters D et al. (2015) Environmental changes during the last millennium based on multi-proxy palaeoecological records in a savanna-forest mosaic from the northernmost Brazilian Amazon region. Anais da Academia Brasileira de Ciencias 87: 1623-1651.

Millán A (2015) Bases para la creación de un plan de manejo integral del fuego en el Parque Nacional Canaima, Venezuela. Master Thesis, Universidad Simón Bolívar.

Monteiro P, Balch J, Nepstad D et al. (2014) Abrupt increases in Amazonian tree mortality due to drought-fire interactions. Proceedings of the National Academy of Sciences of the United States of America 111: 6347-6352.

Montoya E and Rull V (2011) Gran Sabana fires (SE Venezuela): A palaeoecological perspective. Quaternary Science Reviews 30: $3440-3444$.

Montoya E, Rull V and Nogué S (2011a) Early human occupation and land use changes near the boundary of the Orinoco and the Amazon basins (SE Venezuela): Palynological evidence from El Paují record Palaeogeography, Palaeoclimatology, Palaeoecology 310: 413-426.

Montoya E, Rull V, Stansell N et al. (2011b) Forest-savannamorichal dynamics in relation to fire and human occupation in the southern Gran Sabana (SE Venezuela) during the last millennia. Quaternary Research 76: 335-344.

Montoya E, Rull V, Stansell N et al. (2011c) Vegetation changes in the Neotropical Gran Sabana (Venezuela) around the Younger Dryas chron. Journal of Quaternary Science 26: 207-218.

Nepstad D, Carvalho G, Barros A et al. (2001) Road paving, fire regime feedbacks, and the future of Amazon Forests. Forest Ecology and Management 154: 395-407.

Nepstad D, Veríssimo A, Alencar A et al. (1999) Large-scale impoverishment of Amazonian forest by logging and fire. Nature 398: 398-401.

Patterson W, Edwards K and Maguire D (1987) Microscopic charcoal as a fossil indicator of fire. Quaternary Science Reviews 6: 3-23.

Piperno D, McMichael C and Bush M (2015) Amazonia and the Anthropocene: What was the spatial extent and intensity of human landscape modification in the Amazon Basin at the end of prehistory? The Holocene 2: 1-10.

Rodríguez I (2004) Conocimiento indígena vs cientifico: el conflicto por el uso del fuego en el Parque Nacional Canaima, Venezuela. Interciencia 29: 121-129.

Rodríguez I (2007) Pemón perspectives of fire management in Canaima National Park, southeastern Venezuela. Human Ecology 35: 331-343.

Rodríguez I and Sletto B (2009) Apök hace felíz a Patá. Desafíos y sugerencias para una gestión intercultural del fuego en la Gran Sabana. Anthropologica 53: 111-125.

Rodríguez I, Sletto B, Bilbao B et al. (2013) Speaking of fire: Reflexive governance in landscapes of social change and shifting local identities. Journal of Environmental Policy and Planning. Available at: http://dx.doi.org/10.1080/15239 08X.2013.766579.

Rull V (1999) A palynological record of a secondary succession after fire in the Gran Sabana, Venezuela. Journal of Quaternary Science 14: 137-152.

Rull V (2007) Holocene global warming and the origin of Neotropical Gran Sabana in the Venezuelan Guayana. Journal of Biogeography 34: 279-288.

Rull V (2009) New Palaeoecological evidence for the potential role of fire in the Gran Sabana, Venezuelan Guayana, and implications for early human occupation. Vegetation History and Archaeobotany 18: 219-224. 
Rull V, Montoya E, Nogué S et al. (2012) Ecological palaeoecology in the Neotropical Gran Sabana region. Perspectives in Plant Ecology, Evolution and Systematics 15: 338-359.

Rull V, Montoya E, Vegas-Vilarrúbia T et al. (2015) New insights on palaeofires and savannisation in northern South America. Quaternary Science Reviews 122: 58-165.

Schubert C and Huber O (1989) La Gran Sabana panorámica de una región. Caracas: Cuadernos Lagoven.

Schubert C, Briceño H and Fritz P (1986) Paleoenvironmental aspects of the Caroní-Paragua River Basin (Southeast Venezuela). Interciencia 11: 278-289.

Sletto B (2008) The knowledge that counts: Institutional identities, policy science and the conflict over fire management in the Gran Sabana, Venezuela. World Development 36: 1938-1955.

Sletto B and Rodríguez I (2013) Burning, fire prevention and landscape productions among the Pemón, Gran Sabana, Venezuela: Toward an intercultural approach to wildland fire management in Neotropical Savannas. Journal of Environmental Management 115: 155-166.

Strauss R (1992) El tiempo prehispánico de Venezuela. Caracas: Fundación Eugenio Mendoza.

Tinner W, Conedera M, Ammann B et al. (1998) Pollen and charcoal in lake sediments compared with historically documented forest fires in southern Switzerland since AD 1920. The Holocene 8: 31-42.

Tinner W, Hubschmid P, Wehrly M et al. (1999) Long-term forest fire ecology and dynamics in southern Switzerland. Journal of Ecology 82: 273-289.

Urrego D, Bush M, Silman M et al. (2013) Holocene fires, forest stability and human occupation in south-western Amazonia. Journal of Biogeography 40: 521-533.

Wijmstra T and van der Hammen T (1966) Palynological data on the history of savannas in northern South America. Leidse Geologische Mededelingen 38: 71-90. 